パネルディスカッション

\title{
真菌感染と宿主抵抗性
}

\section{真菌感染と Phagocytosis}

\author{
深沢 義村 加賀谷けい子 篠田 孝子 \\ 明治薬科大学微生物学教室
}

\begin{abstract}
病原性酵母の感染防御に括ける食作用（Phagocytosis）の役割を 明らかにするために, 末梢血白血球 (PBL, 主として PMN) と腹 腔マクロファージ (PMP) の Candida albicans に対する食菌能拉 よび殺菌能の差, 食細胞の種による機能の相違, 体液性成分の食菌 に和よぼす影響および Cryptococcus neoformans の莢膜と食作用の関 係を検討した。

C. albicans に対しては，モルモットとマウスの PBL と PMP は
\end{abstract} 同じ食菌能を示したが，PBL の殺菌能はモルモットが最も高く， 次いでヒト，マウスの順であつた.モルモットとマウスの PMP の 殺菌能は PBL に比較して低かつたが, リンフォカインで培養した マウスの PMP では殺菌能が増強された. PBL と PMP において 補体は食菌率を增加させたが，この系に抗体を加えても食作用に 変化はみられなかつた. EGTA と $\mathrm{Mg}^{\#}$ を用いた実験により $C$. albicans に対する正常オプソニンはプロパージンであることが示唆 された。

C. neoformans に対するモルモットの食作用に拈いては，PBL は 補体の存在下で薄い萊膜株に対しては高い食菌および殺菌率を示し たが，厚い萊膜株に対する食作用は明らかな低下を示した. PMP の 食作用は C. albicans の場合と同様に PBL のそれよりも低く, ま た免疫血清には食作用増強効果はみられなかつた。

真菌感染に拈ける抵抗性の機序については, 感染初期にはプロパ ージン系と PMN が重要な役割を演じていることが示唆されたが， また感作リンパ球出現後には活性化された MP も関与するものと 考えられる。

最近深在性真菌症と宿主の防御機構との関係が論議さ れ，真菌免疫に和ける細胞性免疫の重要性が指摘 ${ }^{1,2)}$ れている。一方，食作用 (Phagocytosis) が微生物感染 に対する宿主の正常および特異的免疫機構の中で重要な 役割を演じていることはよく知られているが，病原性酵 母に対する食作用に関しては系統的研究が少なく不明の
点が多い、そこでわれわれはヒト，モルモット，マウス の末梢血白血球抢よびモルモットとマウスの腹腔マクロ ファージについて，C. albicans およびC. neoformans に 対する食菌能, 細胞内殺菌能, オプソニンの役割につい て検討し, 正常和よび免疫食作用の真菌感染に対する抵 抗性の意義を明らかにすることを試みた。 


\section{実験材料と方法}

1）使用菌株および培養：菌株としては当教室保存株 の C. albicans J-1012, type A, C. neoformans Duke, $C$. neoformans A J-4290を用い，0.5\%イーストエキストラ クト（Difco）を含む $2 \%$ ブドウ糖サブロー液体培地で $27^{\circ} \mathrm{C} ， 3 \sim 5$ 日間振盪培養を行つた後, 生理食塩水で洗 浄して用いた。

2）食細胞：ヒト, Hartley 系モルモット拉よび ICR 系マウスの末梢血白血球（PBL）とモルモット拈よび ICR または C $57 \mathrm{BL} / 6$ 系マウスの腹腔マクロファージ (PMP) を用いた. PBL の分離には Boyum の方法 ${ }^{3)}$ を用い，混入した赤血球を $0.2 \% \mathrm{NaCl}$ で処理 ${ }^{4)} し て$ 溶血 させた後に Hanks balanced salt solution (HBSS) で2 回洗浄して用いた。この $\mathrm{PBL}$ 中の $\mathrm{PMN}$ と単球の比は 約 $9: 1$ であつた。

3）オプソニン：同系動物の新鮮血清特よび抗 $C$. albicans J-1012 ウサギ血清（凝集素価 1 ：1280）また は抗 C. neoformans AJ-4290 ウサギ血清（凝集素価 1 : 1280）を用いた。

4）食菌率の測定：C. albicans に対する食菌率の測定 は小試験管法で行つた。すなわち，シリコン処理した小 試験管に食細胞とC. albicans をそれぞれ $2 \times 10^{6}$ 入れ， 新鮮血清 $0.1 \mathrm{ml}$ ，抗血清 $0.1 \mathrm{ml}$ を加光，HBSS で全量を $1 \mathrm{ml}$ とし， $37^{\circ} \mathrm{C}$ 恒温水槽中で $20 \mathrm{rpm}$ で回転させ，一定 時間後にその 1 滴を血算板にとり，食細胞外の菌数を測 定して食菌率を求めた。

C. neoformans に対する食菌率の測定は monolayer 法 で行つた。すなわち，食細胞の $2 \times 10^{6} / \mathrm{ml}$ の懸濁液を $24 \times 12 \mathrm{~mm}$ のカバーグラス上に $0.25 \mathrm{ml}$ ずつ載せ，炭酸 ガス培養器中に 1 時間放置した後 Medium-199で洗浄し て非付着細胞を除去して monolayer を作製し, シャ一 レ(Falcon, No. 3002) に新鮮血清0.375ml, 抗血清0.25 $\mathrm{ml}$, C. neoformans $2 \times 10^{6}$ を入れ, Medium-199で全量を $2.5 \mathrm{ml}$ とした中に monolayer 4 枚を入れ，炭酸ガス培 養器中で $20 \mathrm{rpm}$ の回転下で食菌させた. 一定時間後にカ バーグラスを細胞付着面を下にしてスライドグラスに固 定し，鏡検して菌を取りこんでいる細胞の全細胞に対す る割合を測定し, 食菌率とした。

正常オプソニンを検討するためには $10 \mathrm{mM}$ の EGTA

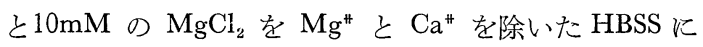
加える系7を用いた。

5）細胞内殺菌能の測定 : 上記の monolayer 法によ り菌を取り込ませ，一定時間後に $2 \times 10^{-3} \mathrm{M}$ のメチレン
青を加光て冷所に置き, 15分後に鏡検して細胞内の菌の 生死をメチレン青の排除試験 ${ }^{8)} に よ り$ 判定した.

6) 粗リンフォカイン: C5 7BL/6系マウスの脾細胞 およびリンパ節細胞を Eagle MEM 培地 (Flow Laboratories）に $1 \times 10^{7} / \mathrm{ml}$ の割合で懸濁し, Concanavalin A (Con A, Sigma Chemicals Co.) $10 \mu \mathrm{g} / \mathrm{ml}$ と共に24時 間培養し，この上清を Sephadex G-15, $10 \mathrm{mg} / \mathrm{ml}$ と共に 30分間擋拌して Con A を除去し, PBS で透析後濃縮し たものを粗リンフォカインとしだ9). また Con A を加 えずにリンパ球を培養した上清を対照とした。リンフォ

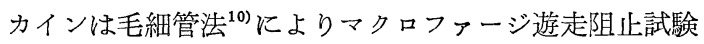
を行い，60\%の遊走率を示す濃度で使用した。

7）活性化マクロファージ：C57BL/6 系マウスの PMP をリンフォカインと共に 3 日間培養し, C. albicans に対する細胞内殺菌能および食菌に伴う chemiluminescence を測定した. Chemiluminescence は Allen らの 方法 ${ }^{11)}$ にしたがい，ルミノール飽和 FCS の存在下でザ イモサンを取り込ませ, 液体シンチレーションカウンタ 一を用いて室温で測定した。

\section{実験結果}

\section{C. albicans に対する食菌におよぼすオプソニンの効} 果

モルモットの $\mathrm{PBL}$ を. albicans と共に小試験管中で 回転させた場合に，HBSS のみでは食菌はおこらず，ま た抗血清を加えた場合にも HBSS と比べて取り込みの 増強は和こらなかつた。これに対して新鮮血清を加えた 場合には30分で約 $95 \%$ の菌が取り込まれた。また新鮮血 清に抗血清を加えた場合にも食菌の増強効果は特にみら

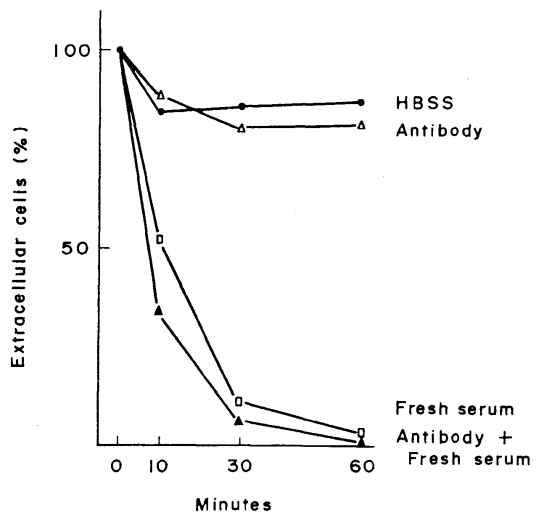

Fig. 1. Effect of serum factor on phagocytosis of C. albicans by normal guinea pig peripheral blood leukocytes 


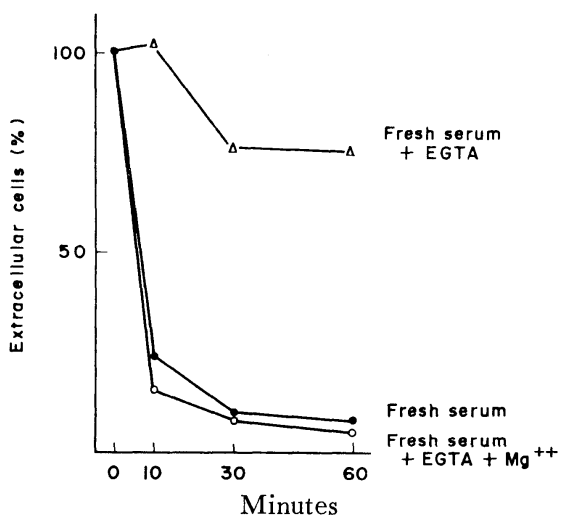

Fig. 2. Effect of EGTA and $\mathrm{Mg}^{*}$ on phagocytosis of C. albicans by normal guinea pig peripheral blood leukocytes

れなかつた (Fig. 1).この結果は，C. albicans の食菌 は正常オプソニンで十分に扣こり, 特に免疫オプソニン を必要としないことを示している。

\section{C. albicans に対する正常オプソニンの検討}

新鮮血清中に含まれる正常オプソニンを検討するため に, 新鮮血清に EGTA と $\mathrm{MgCl}_{2}$ を加えた系を用いて モルモットの PBL による食菌実験を行つた. Fig. 2 に示すように, 新鮮血清に $10 \mathrm{mM}$ の EGTAを加えて $\mathrm{Mg}^{\#}$ 之 $\mathrm{Ca}^{\#}$ を除去し補体活性化の正経路 (classical pathway) と別経路 (alternative pathway) の両者を遮断 した系では食菌はわずかしか抗こらなかつたが， EGTA と $\mathrm{MgCl}_{2}$ を加えて Ca* のみを除去し別経路のみが働 くよらにした系では新鮮血清と同様の食菌がみられた。 これらの結果より C. albicans に対する正常オプソニン は補体のプロパージン系であることが示された。

\section{食細胞の種類によるC. albicans に対する食菌能の} 比較

モルモットおよびマウスの PBL と PMP を用いて 食細胞の種類および動物種による食菌能の比較を行つ た. マウスの PBL, モルモット执よびマウスの PMP はすべて Fig. 1 に示すモルモットの PBL と同様の食 菌率のパターンを示し, PBL と PMP の差扣よびモル モットとマウスの差はみられなかつた.

食細胞の種類および動物種による C. albicans に対 する細胞内殺菌能の比較

ヒト，モルモット执よびマウスの PBL とモルモット 扎よびマウスの PMP の C. albicans に対する細胞内殺 菌能を比較した. PBL の殺菌能については Fig. 3 に示

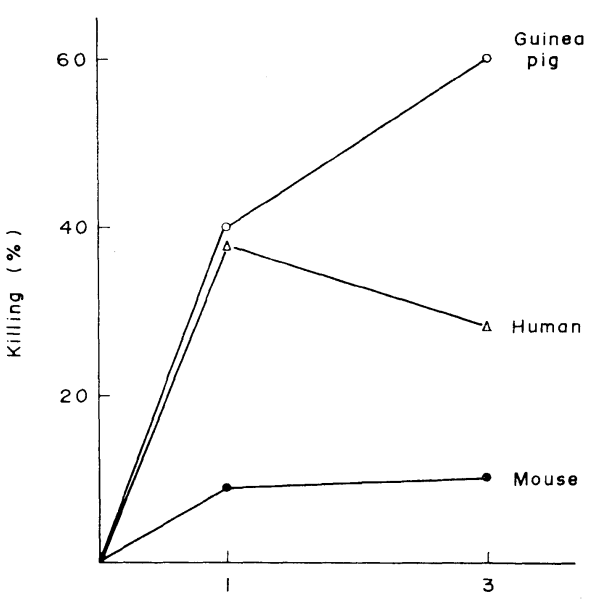

Hours

Fig. 3. Intracellular killing of C. albicans by normal peripheral blood leukocytes

すように，モルモットの $\mathrm{PBL}$ が最も高い殺菌率を示 し，次いでヒト，マウスの順であつた。梞た PMP の場 合にも，モルモットの PMP は食菌開始 3 時間後に約 10 \%の殺菌率を示したが，マウスの PMP は $3 \%$ を殺菌し たのみであり， PBL および PMP の殺菌能には動物種 によつて差があることが示された。

$\mathrm{PBL}$ と PMP の細胞内殺菌能を比較した場合には, モルモットでは PBL の殺菌率 $60 \%$ 対して PMP は 10\%の殺菌率しか示さず，マウスの場合も $\mathrm{PBL}$ の $10 \%$ に対して PMP は3\%の殺菌率を示したのみで, いず れも PMP は PBL と比較して低い殺菌能を示した. また PMP 中では germ tube の形成は活発で細胞を破 壊したが，PBL 中では germ tube の形成は抑制された.

活性化マクロファージの $\boldsymbol{C}$. albicans に対する殺菌能 正常マウスの PMP をリンフォカインと共に3 日間 培養した後 C. albicans に対する殺菌能を測定した. そ の結果, Fig. 4 に示すように Medium-199で培養した場 合の殺菌率は $3 \%$ であり, 対照上清で培養した場合の殺 菌率は22\%を示したが，リンフォカインと共に培養した 場合には殺菌率は50\%と著明に增加した。

リンフォカインにより活性化されたマクロファージの 殺菌能の増加を知るために, ザイモサンを取り込ませた 場合の chemiluminescence を測定した。 その結果,リ ンフォカインと共に 3 日間培湌した PMP は対照上清 と共に培養した PMP の3.6倍の chemiluminescence を 示し, singlet oxygen の産生が増加していることが示さ れた。 


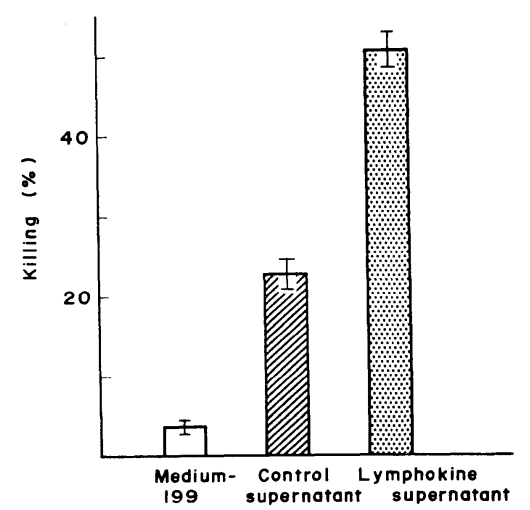

Fig. 4. Effect of lymphokine on intracellular killing of $C$. albicans by mouse peritoneal macrophages

以上の結果より, 細胞性免疫の成立した動物ではりン フォカインによりマクロフアージが活性化され, singlet oxygen の産生が増加して C. albicans に対する殺菌能が 増強されることが示唆された。

\section{C. neoformans に対するモルモットの食作用}

C. neoformans の薄い萊膜株 (AJ-4290) 之厚い萊膜株 (Duke) に対するモルモットの PBL と PMP の食菌能 を検討した。 その結果 Fig. 5 に示すように，新鮮血清

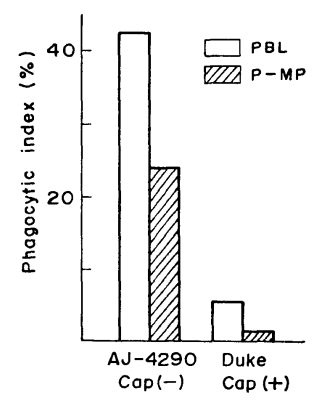

Fig. 5. Effect of capsule on phagocytosis of $C$. neoformans by normal guinea pig peripheral blood leukocytes and peritoneal macrophages

の存在下で PBL でも PMP でも Duke 株に対する食 菌率はAJ-4290株に対与る食菌率よりも明らかに低く, 萊膜は食菌に対する阻書効果をるつことが示された。

次に AJ-4290株に対するモルモットの PBL と PMP の食菌に必要なオプソニンを検討した。

PBL と PMP のいずれの場合にも Medium-199また は抗血清のみでは食菌は持こらなかつたが，新鮮血清の
存在下では食菌 1 時間後に PBL では $42 \%$, PMP では $22 \%$ 食菌率を示し, この系に抗血清を加えた場合にも 食菌率の増加はみられなからた。また EGTA と $\mathrm{Mg}^{\mathrm{N}}$ を 用いた実験により AJ-4290株に対する正常オプソニンも C. albicans と同様にプロパージン系であることが示され た.

PBL と PMP の AJ-4290株に対する細胞内殺菌能を 測定した結果，食菌 3 時間後の殺菌率は PBL では $41 \%$

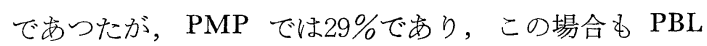
の方が高い殺菌率を示した.

以上の結果より，C.neoformans の食作用に执いては 萊膜が食菌に対する抵抗性を示し，萊膜の薄い株におい ては正常オプソニンはプロパージン系であり，食菌後は PBL の方が PMP よりも高い殺菌能をるつことが示さ れた。

\section{考察}

深在性真菌症の多くは opportunistic infection として 知られているが，その発症機序については多形核白血球

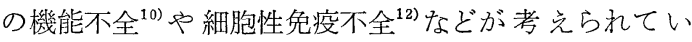
る.

正常防御機構としては食作用が重要な役割を演じてい るが，C. albicans の食作用に拈ける PMN と MP の役 割を考皇た場合に，食菌の段階に拈いては PMN と MP の機能に差はみられなかつた。しかし, 細胞内殺菌の段 階に括いては PMN は MP よりも明らかに強い殺菌能 を示した. 慢性肉芽腫症やミエロペルオキシダーゼ欠損 など PMN の殺菌系に障畫のある人にカンジダ症が多 くみられることが知られており，C. albicans に対する正 常防御機構に括いては PMN が重要な役割を演じると 考㝋られる.

C. albicans に対する食菌は新鮮血清の存在下で汴ぼ完 全に行われた.C. albicans に対しては自然抗体が多くの ヒトや動物に見出されるため, 正常動物の新鮮血清中の オプソニンとしては, 自然抗体を介する補体の正経路 (classical pathway) の活性化と, ザイモサンのような 細胞壁多糖類による補体のプロパージン系の活性化の 2 つの経路が考えられる. 今回の実験で, EGTA と $\mathrm{Mg}^{*}$ を用いて Ca\# のみをキレートし補体の正経路を遮断し た系でも対照の 新鮮血清と同様の 食菌が括こることか ら, 新鮮血清中の正常オプソニンはプロパージン系であ ることが示された。

C. albicans に対する体液性抗体がマウスに物いて感染

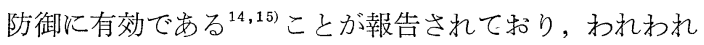


の以前の実験に拈いてもマウスにおいて体液性抗体が感 染防御に関与している結果 ${ }^{16)}$ が得られている. しかし， この度の実験から特異抗体は in vitro に扣いて食作用を 増強しないことが明らかにされた。したがつて体液性抗 体は㹸そらく canditoxin の中和によつて感染防御に関 与していると考光られる。

動物種による食細胞の機能の差を検討した結果, 食菌 能には差はみられなかつたが，モルモットの PBL と PMP は共にマウスの場合よりも高い殺菌能を示し，ま たヒトの PBL はモルモットより低いがマウスよりも 高い殺菌能を示した. モルモットはヒトと同様に $C$. albicans の感染に対してマウスよりも抵抗性である ${ }^{17)}$ の報告があるが，細胞内殺菌能の差はこの結果とよく一 致すると思われる。

C. albicans は軽度の細胞内寄生性をもち, 結核菌やリ ステリア菌と同様にリンフォカインによるマクロファー ジの活性化 ${ }^{18)}$ が感染防御に重要であると考劣られる. 今回の実験ではリンフォカインはマクロファージの $C$. albicans に対する殺菌能を著明に増強し，この活性化の 機構としては singlet oxygenの産生増加が示唆された。

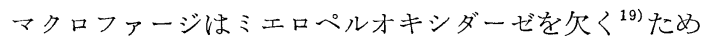
に通常は singlet oxygen を spontaneous に産生するの みであるが，活性化されるとミエロペルオキシダーゼが 産生されるかあるいは spontaneous の系の活性化が抏こ り, singlet oxygen が産生されると考光られ，C. albicans の感染防御に細胞性免疫がマクロファージの活性化を通 して関与していることが示唆された。

C. neoformans の食作用実験において, 厚い萊膜株は薄 い萊膜株よりも明らかに食菌に抵抗し, 莢膜の抗食作用 性 $^{20)}$ が証明された。薄い萊膜株はプロパージン系の活性 化によりオプソニン化されるが，人工培地や土壌中で薄 い莢膜しかもたない株でも組織培埕中では厚い萊膜をも つようになるとの報告 ${ }^{21)}$ もり，C. neoformans の感染防 御には抗萊膜抗体が重要な役割を演じると考えられる. 今回使用した抗血清は食菌を増強しなかつたが，こ扎は 薄い莢膜株で作製したものであり, 今後厚い萊膜株で作 製した抗萊膜抗体を用いて C. neoformans の感染防御に おける特異抗体の役割を検討する必要があると考える.

\section{文献}

1) Kirkpatric, C.H., Rich, R.R. \& Bennet, J.E.: Chronic mucocutaneous candidiasis: Modelbuilding in cellular immunity. Ann. Intern. Med., 74, 955-978, 1971.
2) Rothschild, H., Wilson, M., Lopez, M., Salvaggio, J. \& Bice, D.: An immunological investigation of a family with chronic mucocutaneous candidiasis. Int. Archs. Allergy Appl. Immun., 52, 291-296, 1976.

3) Boyum, A.: Separation of leucocytes from blood and bone marrow. Scand. J. Clin. Lab. Invest., 21, Suppl. 97- , 1968.

4) Johnston, R.B. Jr., Misra, H.P., Lehmeyer, J.E., Webb, L.S., Baehner, R.L. \& Rajagopalan, K.V.: The role of superoxide anion generation in phagocytic bactericidal activity. J. Clin. Invest., 55, 1357-1372, 1975.

5) Leijh, P.C., van den Barselaar, M.T. \& van Furth, R.: Kinetic of phagocytosis and intracellular killing of Candida albicans by human granulocytes and monocytes. Infect. Immun., 17, 313-318, 1977.

6) Baughn, R.E. \& Bonventre, P.F.: Cellmediated immune phenomena induced by lymphokines from splenic lymphocytes of mice with chronic staphylococcal infection. Infect. Immun., 11, 313-319, 1975.

7) Forsgren, A. \& Quie, P.G.: Opsonic activity in human serum chelated with ethylene glycoltetra-acetic acid. Immunology, 26, 1251-1255, 1974.

8) Schmid, L. \& Brune, K.: Assessment of phagocytic and antimicrobial activity of human granulocytes. Infect. Immun., 10, 1120 $1126,1974$.

9) Gately, M.K., Gately, C.L., Henney, C.S. \& Mayer, M.M.: Studies on lymphokines: The production of antibody to guinea pig lymphotoxin from migration inhibitory factor and mitogenic factor. J. Immunol., 115, 817826, 1975.

10) George, M. \& Vaughan, J.H.: In vitro cell migration as a model for delayed hypersensitivity. Proc. Soc. Exp. Biol., 111, 514-521, 1962.

11) Allen, R.C. \& Loose, L.D.: Phagocytic activation of a luminol dependent chemiluminescence in rabbit alveolar and peritoneal macrophages. Biochem. Biophys. Res. Commun., 69, 245-252, 1976.

12) Lehrer, R.I. \& Cline, M.J.: Interaction of Candida albicans with human leukocytes and serum. J. Bacteriol., 98, 996-1004, 1969.

13) Lehrer, R.I. \& Cline, M.J.: Leukocyte myeloperoxidase deficiency and disseminated candidiasis: The role of myeloperoxidase in resistance to candida infection. J. Clin. Invest., 48, 1478-1488, 1969. 
14) Mourad, S. \& Friedman, L.: Passive immunization of mice against Candida albicans. Sabouraudia, 6, 103-105, 1968.

15) Pearsall, N.N., Adams, B.L. \& Bunni, R.: Immunologic responses to Candida albicans. III. Effects of passive transfer of lymphoid cells or serum on murine candidiasis. J. Immunol., 120, 1176-1180, 1938.

16) 深沢義村, 篠田孝子, 加賀谷けい子, 西川朱 実：カンジダ症の免疫機序に関する実験的研 究. 真菌誌, $17: 64-68,1976$.

17) Hurley, D.L. \& Fauci, A.S.: Experimental disseminated candidiasis. I. An experimental model in the guinea pig. J. Infect. Dis., 131, 516-521, 1975.

18) Nathan, C.F., Karvanovsky, M.L. \& David,
J.R.: Alterations of macrophage functions by mediators from lymphocytes. J. Exp. Med., 137, 275-290, 1973.

19) van Furth, R., Hirsch, J.G. \& Fedorko, M.E.: Morphology and peroxidase cytochemistry of mouse promonocytes, monocytes, and macrophages. J. Exp. Med., 132, 794-805, 1970.

20) Bulmer, G.S. \& Sans, M.D.: Cryptococcus neoformans. II. Phagocytosis by human leukocytes. J. Bacteriol., 94, 1480-1483, 1967.

21) Farhi, F., Bulmer, G.S. \& Tacker, J.R.: Cryptococcus neoformans. IV. The not-so encapsulated yeast. Infect. Immun., 1, 526531, 1970.

\section{Phagocytosis in Fungus Infection \\ Yoshimura Fukazawa, Keiko Kagaya and Takako Shinoda \\ Department of Microbiology, Meiji College of Pharmacy, 35-23, Nozawa-1, Setagaya-ku, Tokyo 154, Japan}

The study of phagocytosis of Candida albicans and Cryptococcus neoformans by human, guinea pig and mouse peripheral blood leukocytes (PBL) and guinea pig and mouse peritoneal macrophages (PMP) in vitro has been performed to elucidate the role of phagocytosis in host defense mechanism against systemic mycoses. Although C. albicans was ingested by guinea pig and mouse PBL and PMP in the same rates in the presense of fresh serum, the killing rates of intracellular $C$. albicans in these phagocytes were not the same showing a high ability of guinea pig and a low of mouse phagocytes. The human PBL showed an intermediate killing ability between them. Moreover, intracellular killing abilities of guinea pig and mouse PMP were lower than those of PBL. The killing capacity of mouse PMP increased remarkably when the PMP had been cultured previousely with lymphokines for 3 days. The PBL and PMP ingested C. albicans almost completely in the presense of fresh serum alone, and no more enhancement of ingestion was shown when specific antibody was added to this system. The results of phagocytosis in vitro using EGTA and $\mathrm{Mg}^{\#}$ indicate that normal opsonin for C. albicans is factors of properdin system in fresh serum. Guinea pig PBL and PMP ingested encapsulated strain of $C$. neoformans more effectively than nonencapsulated strain, and specific antibody did not enhance ingestion of both strains of $C$. neoformans. It might been suggested that properdin system and PMP play an important role at the primary stage of Candida or Cryptococcal infections and that activated macrophages participate in the host defense mechanism after induction of sensitized lymphocytes. 